\title{
California and Irony in Mad Men
}

\section{RODNEY TAVEIRA}

UNIVERSITY OF MELBOURNE

\begin{abstract}
What a lucky man, indeed-chronically restless, temperamentally anxious, a man in constant motion to prove what ultimately cannot be proved: that he is a real man and that this identity is unthreatened by the action of other men.
\end{abstract}

Alexis de Tocqueville, Democracy in America ${ }^{1}$

This essay will suggest ways of reading the multiple and duplicitous social and intimate relations in AMC's television series Mad Men (2007-). The show is set in the 1960s and it seeks to represent the prevailing mores of its period by following the lives of the men and women working at a Madison Avenue advertising agency. I will examine the movements of the show's central character Don Draper, the agency's star creative director. The handsome and mysterious Don moves through various work, domestic and leisure spaces, tangling with the women he finds there. He flees these increasingly complex social spaces by visiting California near the end of season two. This movement signifies a queer refusal of the family in favour of an 
ironic selfhood. California refracts the two-faced biography of Don, who is really Dick Whitman, the orphaned son of a prostitute who stole his dead commanding officer's identity during the Korean War. Don spends time with the 'real' Mrs Draper in California, lazing in a cinematic milieu and suspending his responsibilities to family and work. This essay will also delineate what happens when the cinematic space of California is met by a habitué of television melodrama, ask what kinds of social and intimate relations are either necessary for or result from this meeting, and argue for irony as the show's critical mode of representation.

\section{-PREPOSTEROUS MEN: MELODRAMA PAST AND PRESENT}

In an essay that bemoans the representation of business in popular televisual and cinematic culture, Larry E. Ribstein criticises Mad Men for its paucity of detail. The show's characters do not 'interact in a more convincing environment [as] in television shows about the police (The Wire) or the mob (The Sopranos) or in the novels of Anthony Trollope'. ${ }^{2}$ This claim is curious but also suggestive because the almost fetishistic evocation of the 1960s-the fashion, decor and technology, and the organisation of the office and home-is precisely for what the show is popularly and critically praised. ${ }^{3} \mathrm{He}$ also argues that popular representations of business as criminal or unethical have led to a greater public disdain which has in turn influenced the desire to prosecute, in particular, financiers who might otherwise be considered good citizens. ${ }^{4}$ While the popular reaction to Ribstein's argument-'How can he defend Bernie Madoff?'-might be taken as evidence for his argument about popular culture condemning business, ${ }^{5}$ Ribstein goes further, seeking to reverse the popular argument: 'Indeed, businesspeople might credibly claim moral superiority. After all, business is about helping others to express themselves by buying things' ${ }^{6}$ Ribstein's italics bracket off the purpose of business: 'business is about helping ... by buying things'. But this is perfectly symmetrical with Ribstein's analysis of Mad Men's advertisers: 'They tune into other people's dreams so they can furnish them their clients' products.' ${ }^{\prime 7}$ In other words, Mad Men represents its advertisers in their morally superior role of helping others to express themselves. Whence Ribstein's problem?

The answer is found in melodrama. The show's social and intimate relations are so contrived, so-as I will argue-queer, that Ribstein overlooks Mad Men's 
favourable representation of business and his own criterion for quality TV (the convincing evocation of environment). What proves intractable is the show's duplicity: 'An airplane can be a place for vicarious sex or a magic ship that brings daddy home.' 8 The implicit perversity of itemising the fantasy of casual sex alongside the innocent imagination of childhood repeats rhetorically an admixture of quality and lowbrow TV that Ribstein cannot admit.

Daniel Mendelsohn more pointedly criticises Mad Men along similar lines. The enormous popularity of the show among young adults (those too young to remember directly the period it represents) is based, he says, on a fantastic attraction, 'an alluring historical fantasy of a time before the present era's seemingly endless prohibitions against pleasures once taken for granted ... The show's style is, essentially, symbolic'. ${ }^{9}$ Mendelsohn, like Ribstein, takes issue with what he sees as the comparative failure of Mad Men when viewed against The Wire, The Sopranos, and other emblematic examples of this current golden age of television:

With these standouts ... Mad Men shares virtually no significant qualities except its design. The writing is extremely weak, the plotting haphazard and often preposterous, the characterizations sallow and sometimes incoherent; its attitude toward the past is glib and its self-positioning in the present is unattractively smug; the acting is, almost without exception, bland and sometimes amateurish. ${ }^{10}$

While Mendelsohn allows Mad Men's quality design and is more perspicacious than Ribstein regarding the show's 'convincing environment', the quoted paragraph is, essentially, symbolic, and it is worth attending to the constituents of this collective symbol for they reveal the show's social and intimate relations. Mendelsohn decodes his pejorative figuration of soap opera and melodrama in the following paragraph: worst of all ... the show is melodramatic rather than dramatic ... It proceeds ... like a soap opera, serially (and often unbelievably) generating, and then resolving, successive personal crises ... rather than exploring, by means of believable conflicts between personality and situation, the contemporary social and cultural phenomena. ${ }^{11}$

Mendelsohn correctly diagnoses the seriality of soap opera and the generative incredibility of melodrama that bespeak the generic, temporal and social tensions in Mad Men, but he describes his diagnosis as malignant. 
Mendelsohn specifically cites Don Draper's genealogy as evidence of weak writing. The son of a prostitute who died in childbirth, Dick Whitman is raised poor by his imperious father and a strict Christian stepmother in Depression-era rural Pennsylvania. Dick witnesses his father being killed when a startled horse kicks him in the face. He joins the army and after a shelling in the Korean War that kills his commanding officer, he steals this man's identity by switching their dog tags. Returning to the United States, 'Don' sells used cars before being tracked down by Anna Draper, who is looking for her husband. Somehow, they begin a mutually fulfilling relationship. Anna plays her part in Don's masquerade, granting him a divorce when he wants to marry advertisement model Betty Hofstadt. Don writes copy for advertisements for fur coats. He gets his career break into the Sterling Cooper advertising agency after getting a senior partner drunk and turning up for work the next day claiming he had been hired during their bout of inebriation.

It seems that Mendelsohn objects to arbitrary plot movements and characterisations that lack a coherent and stable line of reference or causation. But this so-called 'preposterousness' (literally, placing things in the wrong order) of plot is a product of the show's genealogy of melodrama and its representation of memory. Like its generic cousins, contemporary daytime soap operas such as The Days of Our Lives and The Bold and the Beautiful and 1980s evening 'power soaps' such as Knots Landing and LA Law, Mad Men is principally concerned with the present. ${ }^{12}$ This present, what Mendelsohn calls a smug-self-positioning, is fraught with past actions, actions so enduringly effective that they result in the infamous stultification of soap opera: frozen gestures and bodies; dialogue that continually reiterates past relations, carried out with characters turning their backs against one another; too-long stares and silences before a scene is cut. These languors are punctuated by explosive expressions of desire: sex and violence; death and revenge; the revelation of traumatic and bogus pasts. The insistence of the past on the present structures Mad Men and this is compounded by the show being set in the past.

Indeed, a visuospatial equivalent of hysteron proteron (the rhetorical figure of preposterousness that disorders past and present) is a key structural element of Mad Men. New York is the space of the present, the chronological, verifiable space in which the show takes place: period detail such as clothing, decor and art; 
recreations of real hotels and restaurants; representations of historical events like the Cuban missile crisis and the Kennedy assassination when they were current affairs. This fidelity to surface, space, and past experience cannot help but also fetishise time. The present-New York City, which spreads out to include the Draper family home in upstate Ossining-is peopled with Don, his family and the Sterling Cooper advertising agency.

This present is tempered by a hazy past that interjects and is accessed in moments of ennui, reverie, hysteria and fainting, usually precipitated by one of Don's signature 'thousand mile stares' when looking into a mirror, at an image or scene that triggers a memory, or before he passes out from alcohol, drugs or sickness. This past is peopled with Dick Whitman, Don's 'real' or former identity, takes place in rural Pennsylvania, 1950s' California and Korea, and is cast in the forms of dream, memory and fantasy. It is my argument that a contemporaneous California triangulates the formal and narrative insistence of the past on the present in Mad Men and that this triangulation is imaged spatially by Don's travails. An example of the show's global structure of hysteron proteron occurs when it becomes condensed into a kind of visuospatial synchysis (a confused arrangement of words in a sentence) by the material reality of television production. Don is concussed after falling down the stairs of the Draper family home. Groggy, he looks in the direction of the kitchen. We cut to a memory of Abigail, his stepmother, giving birth to a stillborn child. To shoot this memory the crew set up the traumatic scene in what is essentially the kitchen of the Ossining house, into which Don and the camera peers into Pennsylvania past. 13 The hazy past appears in the present and inhabits the same space.

\section{-QUALITY MEN: ART CINEMA, SCREEN MEMORIES}

Perhaps the 'quality' aspect of Mad Men's melodrama can be perceived if we follow Jane Feuer's criteria in her 'HBO and the Concept of Quality TV'. HBO's model of being 'not TV' is founded on, says Feuer, 'claiming to be something else: namely, art cinema or modernist theatre'.14 While Mad Men is shown on AMC and not HBO, its critical accolades and ubiquitous comparisons to The Sopranos and The Wire, and having the same production staff who worked previously on accepted quality TV shows such as The Sopranos (creator Matthew Weiner, director of photography Phil 
Abraham, director Alan Taylor, producer Scott Hornbacher, among others), situate it in the same 'not TV' model.15

Part of quality TV's claims to being not TV is the use of art cinema's techniques such as a dream diegesis, ${ }^{16}$ what Feuer identifies in Six Feet Under as 'subjective wish-fulfilment point-of-view shots' in which 'characters see not reality but rather their desires'.17 The birth of Abigail's stillborn child is represented as a direct memory of Don's as he is present in the scene as a child (as Dick Whitman, of course); here, memory may be accessing reality. Explicit wish-fulfilment is seen when Don impossibly remembers his own birth. Cooking at his stove in Ossining, Don stares off into the distance-again, through synchysis, the kitchen acts as a portal into the past and enacts the show's structural principle of hysteron proteron. We witness his cheapskate father cry poor to a prostitute who will be Don's mother after this assignation cum conception. Smiling at her sass, Don hears the origin of his real name: if she gets pregnant, she promises Archie she will 'cut his dick off and boil it in hog fat'. After she dies giving birth to him, her son is delivered to the doorstep of the Whitman home and introduced thus: 'His name is Dick, after a wish his mother should have lived to see.'

Mad Men repeatedly adopts the dream diegesis of art cinema and by doing so further confuses the already complex story of Don's identity. The scene of Dick's birth is given, impossibly, from Don's point of view. It becomes a screen memory: 'The indifferent memories of childhood owe their existence to a process of displacement: they are substitutes, in mnemic reproduction, for other impressions which are really significant.'18 Freud says screen memories have at least three temporalities and modes of displacement; here, Don's impossible memory of his own birth either displaces the trauma of witnessing the stillborn child, or the memory of the stillborn child displaces the trauma of Dick's birth where his life causes his mother's death and he projects the death onto the stand-in for himself, the stillborn half-brother. ${ }^{19}$ This trauma and its defensive displacement catches up with Don in New York when his surviving half-brother Adam hangs himself after Don rejects Adam's attempt to reconnect with his painful past. Adam, four seasons and seven diegetic years later, functions as a screen memory when he appears ghostly in the final episode of season five, 'The Phantoms'. Don sees a flash of him in the office while suffering the pain of a toothache. Later, receiving nitrous oxide after 
his tooth is extracted, Don carries out a conversation with Adam. The ligature mark on Adam's neck indicates a displacement of Don's guilt from the suicide of Lane Pryce whom, in the previous episode, hanged himself after Don refused to overlook his fraud of the agency's funds and insisted Lane resign.

Like The West Wing, one of Feuer's exemplars of quality TV, Mad Men has a serial structure. For Feuer this means The West Wing is a soap opera in terms of narrative structure although not in terms of melodramatic style'. ${ }^{20}$ In contrast to Mendelsohn, Feuer finds a soap operatic concern with a present comprising many simultaneous storylines and movements to be indicative of quality TV. However, the point of arguing for Mad Men's status as quality TV is not to claim that the show is 'good' or 'worthy' but to recognise one of its critically accepted genealogical strands-art cinema-in order to make apparent and associate that other strandmelodrama-that is habitually denigrated when recognised. This generic multiplicity may designate melodrama as a feature of quality TV; more importantly, it reveals how a melodramatic televisuality can image novel modes of social and intimate relations and, in the case of Mad Men, the archetypal American narrative of the self-made man. But, first, the genealogy of Mad Men's mode of representation must be unbundled in order to recognise how its preposterous narrative structure and its use of place make possible these novel images.

Produced in the twenty-first century, Mad Men is highly, even reflexively conversant with art cinema, which flourished during and after the period in which the show is set. Film and television melodrama was also a dominant mode of popular visual culture in this period. Nina C. Liebman notes that the highest proportion of film melodramas were produced in the late 1950s. ${ }^{21}$ While the numbers wane into the early 1960s, their cinematic codes were integrated into television melodrama that are seen in, for example, 'the texts' obsession with the hyperreal in terms of emotion and narrative [that] is contradicted by a near obsession for "realistic" mise-en-scène'.22 What was once a contradiction between realistic mise-en-scène and an overblown expression of emotion becomes verisimilar in Mad Men in the carefully crafted exterior of Don Draper, a man who appears to have it all: handsomeness, success in business in New York City, beautiful wife, kids, and home, and an upwards social trajectory. What remains contradictory, what 
speaks against the fidelity of facades, is the narrative of Don Draper as a self-made man and a social being whose intimate relations are arbitrary and excessive.

Thomas Elsaesser argues that family melodrama reconfigures 'all social conflict and contradiction into familial issues'.23 By the early 1960s, 'the notion of "family" became much more fluid, it was more explicitly castigated and less frequently offered as a panacea for the problems of the day'. ${ }^{24}$ A close reading of the 'California' episodes of season two reveal how Mad Men combines television melodrama with its own cinematic forebear, plumbing a queer line of affiliation that speaks to (as opposed to 'contradicts') Don's ironic selfhood, its structure, and the form and content of its representation.

-IRONIC MEN: HUMAN ARTEFACTS BETWEEN NEW YORK AND CALIFORNIA

The episode in which knowledge of the closet freely circulates in the offices of Sterling Cooper also sees Don and Pete depart for California to cash in on the booming aerospace industry of the American southwest. ${ }^{25}$ This coincides with Don's abdication of his family and place of work-his identity-for a sojourn with European nomads and with the 'original' Mrs Draper. Titled 'The Jet Set' and 'The Hall of the Mountain King' (which, respectively, connote contemporaneous international travel and Henrik Ibsen's experimentation with dramatic convention), these episodes make apparent the effects of the present's fraught subsistence on the past.

When Ken Cosgrove tells Kurt, after Kurt openly tells co-workers that he is homosexual, that he thinks 'homosexual' must mean something different from wherever the European Kurt originally hails, the question is begged: what else could it mean? Kurt is very clear: 'I love the man, not the woman'. The initial closeted arrival (with Kurt in an amazing cable knit that simply demands to be read like Braille) of the homophonous artistic partners (both are surnamed Smith) signals how homosexuality operates in this echelon of New York: 'We'd prefer it if no one knew we were here.'26 Smitty also distances himself from Kurt's homosexuality by appealing to national differences: 'They do things differently in Europe.'

Appearance and difference similarly operate when Don is looked over by a man reading Frank O'Hara's poetry collection, Meditations in an Emergency, at a bar. Don asks what he is reading. He is overlooked according to his appearance: 'I don't think 
you'd like it.' The book then becomes an object of secret circulation: under the cover of night and an overcoat, taking the family dog for a walk, Don sends this Whitmanesque song of himself to Anna in California. The irony that he is exactly the kind of man who finds O'Hara appealing, or familiar, is a closeted means by which Don can relate to a past that is dangerous to the current manifestation of his 'ironic selfhood'. Richard Rorty, from whom I adapt this designation, describes the field in which the 'liberal ironist' operates:

As I am using the term 'literature' and 'literary culture', a culture that has substituted literature for both religion and philosophy finds redemption neither in a noncognitive relation to a nonhuman person nor in a cognitive relation to propositions, but in noncognitive relations to other human beings, relations mediated by human artifacts such as books and buildings, paintings and songs. These artifacts provide a sense of alternative ways of being human. ${ }^{27}$

Don makes contact with his alternative selfhood through O'Hara, reaching out to his readymade wife in California via a literary object to which he was judged ill suited. In the operation of fantasy and melodrama we see, pace Jacques Lacan and Jacques Derrida (another homophonous pair), that the letter always finds it destination and that it also never leaves: Anna, in California, the destination, says she was immediately reminded of New York, the letter's origin, by the O'Hara collection. O'Hara allows Don to shed partly his current 'Drapery' as he accesses his former 'Whitman', a queer genealogy of noncognitive and searchingly redemptive relations mediated by the human artefact of poetry.

Don follows his epistolary emissary to California, a space, compared with New York, that is less demanding on its subjects in terms of how it structures them and their relations; Don can edge closer to Dick. The infamous hyperreal space of California allows the makers of Mad Men to perform a cinematic sleight of hand and have January Jones play a mirage of herself when Don first arrives at the hotel and thinks he sees Betty, his wife. The second reverse-shot depicts a different actress, blonde and identically costumed. The family flickers as a screen memory as California begins its triangulation of New York/Don and the past/Dick. 
This plastic, fantastic configurability has been a constant figure in the cultural work on California since the 1930s. Erich Maria Remarque, quoted in Mike Davis's City of Quartz:

Real and false were fused here so perfectly that they became a new substance, just as copper and zinc become brass that looks like gold. It meant nothing that Hollywood was filled with great musicians, poets and philosophers. It was also filled with spiritualists, religious nuts and swindlers. It devoured everyone, and whoever was unable to save himself in time, would lose his identity, whether he thought so himself or not.28 Davis finds Jean Baudrillard's and Umberto Eco's postmodern 'adventures of hyperreality' in Los Angeles in strict lineage with Remarque's more contemporaneous account of the development of the city. European émigrés, such as Anton Wagner, then later Theodor Adorno and Bertolt Brecht, believed LA a sorry emulation of cosmopolitan Paris. ${ }^{29}$ Nonetheless, Eastern music, straight out of the orientalist backlot simulacrum of Casablanca, plays across the pool as the concierge, Riccardo, tries to track down Don's missing luggage. But for the clothes on his back Don is bereft of his New York identity insofar as it operates on the surface, contrived in his costume of the man in the grey flannel suit, signifying as queerly-that is, in the same manner-as Kurt's ensembles. ${ }^{30}$ Riccardo suggests the attention of a Chinese tailor as a temporary means to maketh the man. While the way New York has been represented by the makers of Mad Men has received criticism for its lack of representation (that is, its lack of racial and ethnic diversity), there is something distinctly international about California-Eastern music, Hispanic concierge, Chinese tailor-even before Don meets Viscount Monteforte d'Alsace and his coterie of European nomads.

Indeed, non-New York spaces in Mad Men tend to be populated by non-AngloAmericans, and deviant behaviour results. Salvatore Romano, the agency's ItalianAmerican art director and single non-Anglo-American employee-and a closet homosexual-lets himself begin kissing a Hispanic bellhop while on a business trip with Don to Philadelphia, succumbing apparently for the first time to his desire. In New York Sal is constrained. He repeatedly resists come-ons from men. He sublimates his desire for his workmate Ken Cosgrove by investing in Cosgrove's short story that is published in The Atlantic. Again, a literary work becomes, like 
O'Hara's collection, a medium of a hidden identity, a human artefact that provides a sense of alternative ways of being human. The story legitimates an invitation to the Romano home for dinner, one in which Sal's wife feels and expresses her exclusion from the scene of men and their talk of work. Later, Sal's refusal of the amorous advances of Lee Garner Jnr, a good ol' boy of the Lucky Strike tobacco company, sees Sal sacked from the agency, and he is never seen again.

Similarly, Betty and Don role-play a man and a woman meeting for the first time in front of an audience of Italian men whom had been flirting with Betty while the Drapers are on a business trip to Rome. ${ }^{31}$ We marvel at Betty speaking Italian for the first and only time in the show and we see her disrobe before joining Don in their hotel room shower, a display of desire alien to the Ossining home, simply not permissible in the family space; all of Don's (and Betty's) extra-marital trysts take place outside the home.

\section{-NOMAD MEN: CALIFORNIAN COSMOPOLITANISM}

In reflecting on the resentment of women moving into 'men's spaces' that appeared in his interviews with young men for Guyland, Michael Kimmel spotlights Mad Men:

once, it seemed to be so easy to find an arena in which to prove one's manhood. Look at the world portrayed by hit TV show Mad Men-a world where men sustained a casual affability in their homosocially pure arenas, where women were secretarial playthings (or an occasional vixen who inherited daddy's money and power). Things were so much easier when women 'knew their place'. 32

While it is unfair to point out the paucity of Kimmel's rendering of the show given the brevity of his reference and its merely illustrative purpose as an image of a former time, Kimmel's reading of 'homosocial purity' does not take into account the queer and ironic relations that the show puts to work.

It is the following paragraph that unwittingly offers insight into the circulation of ironic selfhood in Mad Men:

Buffeted by changes not of their making, increasingly anxious in an economic and political arena that erodes their ability to be breadwinners, and confused by new demands about emotional responsiveness and involved fatherhood, men seem uncomfortable in that new spotlight, 
shifting uncomfortably, shielding their eyes, even railing against the glare. 33

In California, Don evinces alarm at the montage of multiple independently targetable reentry vehicles (MIRVs) in the inert, white space of the room in which Space Technology Laboratories holds their business presentation. The MIRVs carry an overwhelming payload that exceeds their singular appearance. Fourteen nuclear bombs emerge from a single rocket, each bomb able to find its way to a different target.

This excess is also a product of the 'location' of California, the space of soap opera televisuality:

By definition, comedic story lines [predominantly set in 'generic middle America'] are resolved in favor of family stability and social equilibrium. The evening soaps of the 1980s, in contrast, thrived on the continuing disruption of social norms by J.R. Ewing of Dallas and his counterparts ... By representing different ways in which Americans try to project their understanding of the national frontier into an uncertain future, they translate the range of possible meanings for the nineteenth century nation into the twenty-first century. The result is a direct connection in which even the newest of Western cities draw on the three mythic images of the historic West: democracy, opportunity, and individual fulfillment. ${ }^{34}$

The intercontinental thrust westward, that within America itself if we take Don's spur-of-the-moment trip as indicative of the frontier drive in the American imaginary and Californian boosterism, finds its way into the burgeoning aerospace and weapons industry of California, which directs this thrust beyond national borders and, excessively, into the stratosphere. Don is asked if he is an actor or an astronaut; that is, if he embodies Hollywood or the space industries. But it is the MIRVs that follow a distribution strangely parallel both to Don's serial identity and to the self-proclaimed nomads to which Don is connected by Joy, the young and beautiful woman whom entices Don to abandon his business trip and attend to the ironic work of his manhood of many and varied sexual connections.

Norman M. Klein describes the 'cinematic maps' of the 'City of Lights' as, following Thomas Frank, one of LA's 'machines of forgetting' ${ }^{35}$ But by referring to LA by this image, Klein casts the city by night, with flashpoints of cinematic 
associations appearing against and in a field of darkness. California in Mad Men, on the other hand, is almost exclusively a day-lit space: colour and heat and glare, a two-hour open-top drive down Interstate 10. While Don had shifted uncomfortably at Joy's earlier invitations and at the sight of MIRVs, he adjusts his outlook to California as he dons a new pair of sunglasses and jumps into Joy's convertible to drive to Palm Springs. Three seasons later, it is to this California that Pete Campbell appeals to Beth Dawes to escape with him rather than undergo electroshock therapy for being 'rather blue of late': 'Let's go to Los Angeles. I've been there. It's filled with sunshine.'

Mad Men's California is a kind of Proustian cum Penelopean tapestry, a triangulation of a present that, most obviously for Don, must needs be an act of conscientious remembrance and a past that plays out the negative dramaturgy of forgetting. Walter Benjamin on Proust:

For the important thing for the remembering author is not what he experienced, but the weaving of his memory, the Penelope work of recollection. Or should one call it, rather, a Penelope work of forgetting? Is not the involuntary recollection, Proust's mémoire involontaire, much closer to forgetting than what is usually called memory? And is not this work of spontaneous recollection, in which remembrance is the woof and forgetting the warf, a counterpart to Penelope's work rather than its likeness? For here the day unravels what the night has woven. When we awake each morning, we hold in our hands, usually weakly and loosely, but a few fringes of the tapestry of lived life, as loomed for us by forgetting. However, with our purposeful activity and, even more, our purposive remembering each day unravels the web and the ornaments of forgetting. ${ }^{36}$

What Benjamin describes is an ironic space that, like California, comprises the coincidence of remembering and forgetting, a mutable space lit by the glare of the sun that unravels Don's work to distance himself from Dick and causes him to faint by the pool in Palm Springs, where the nomads reside for the moment. He emerges from his convalescence in a casual outfit that obviously belongs to someone else and he eats Mexican food for the first time. This culinary cosmopolitanism is extended by the accented foreigners in attendance and the 'Places' parlour game where acrostics 
take you around the world. To play Places one names an international city that begins with the final letter of the previously stated city. Don earned his first round of applause when he re-emerges from his faint; his second comes with the utterance of 'Oslo'. Don awakes the next morning to hold in his hands William Faulkner's The Sound and The Fury (that signal modernist experiment with multiple voices and points of view), which he uses to note Anna's address in San Pedro.

—SinthomoseXUAL MEN: THE FUtURE OF DON'S SELFHOOD

In No Future: Queer Theory and the Death Drive, Lee Edelman develops the concept of 'sinthomosexuality': 'this word without a future ... would assert itself against futurity, against its propagation, insofar as it would designate an impasse in the passage to the future and, by doing so, would pass beyond, pass through, the saving fantasy future denotes'. ${ }^{37}$ Edelman finds figures of the sinthomosexual in Victorian literature (Ebenezer Scrooge's “'futuricide" by "hum-buggery"'38), children's animated films ('Scar, the connotatively queer brother of the Lion King'39), and most appositely for Mad Men, Alfred Hitchcock's cinema (Thornhill in Strangers on a Train, Leonard in North by Northwest). These sinthomosexuals have in common a disruptive mode of social and intimate relations. Not following the rules makes possible an alternative field of self-creation, for 'queerness names the side of those not "fighting for the children", the side outside the consensus by which all politics confirms the absolute value of reproductive futurism'.40 In season one, Rachel Menken turns down Don's offer to run away with him because he will be abandoning his children. It is apparent that this consequence had not entered Don's thinking: he only sees his self-made futurity, not the reproductive futurism indicated by his children. In California Don is able to turn away from home, living for weeks out of contact from his family and workplace. Pete attempts to follow Don's gambit when he asks the married Beth Dawes to go with him to Los Angeles. He, like Don in season one, now lives out of New York City, forking east on the train to Cos Cob. He has a child, a doting housewife, a perfect suburban existence. He wants out.

The image of the weave is again employed when Edelman describes the sinthome. Here, the image has its basis in Lacan, where the sinthome functions as a 'quilting point' (point de capiton) that binds the consistency of the Imaginary, the Symbolic and the Real for the subject, stopping the illusion of our smooth, coherent 
subjective reality from being revealed. As Edelman says, 'though it functions as the necessary condition for the subject's engagement with Symbolic reality, the sinthome refuses the Symbolic logic that determines the exchange of signifiers; it admits no translation of its singularity and therefore carries nothing of meaning, recalling in this the letter as the site at which meaning comes undone'. ${ }^{41}$ And just as Lacan shifted from a linguistic to a topological understanding of subjectivity, so too does Mad Men when Dick Whitman, after his entry into the Symbolic, joins the army, and uses the homosocially pure space of the battlement in Korea-just two men are present-to reinscribe the signification of his commanding officer's dog tags and to frame California, his soon-to-be home, as a field for his ironic selfhood.

Dick's entry into the Symbolic occurs in 'The Hobo Code'. In flashback (triggered initially by Don smoking marijuana then looking into a mirror and again when Don, still stoned, looks through a viewfinder), a young Dick is digging holes (as he was when the bombs began to fall in Korea) when a hobo happens across the Whitman farm. He asks for a meal and Abigail, Don's stepmother and a good Christian, offers him a meal and a coin in return for working in their fields the next day. The Hobo remarks that Dick reminds him of himself. Later, Dick asks the Hobo, 'Ain't you heard? I'm a whore child.' Dick is still intensely identified with his mother and imagines that not only is he known beyond the farm, but so too are the circumstances of his birth. ${ }^{42}$ The Hobo replies, 'No, I hadn't heard anything about that.' The Hobo's manners were noted earlier by Abigail; the Hobo is from New York. Dick says he 'doesn't talk like a bum', and the Hobo replies that he is a 'Gentleman of the Rails' for whom 'each day is brand new'. He has turned his back on his family, job, and mortgage; 'Death came to find him', and he avoids death by keeping mobile. The Hobo demonstrates the Hobo Code to Dick, showing him what different signs mean: a stylised pie on your front gate means you cook good food. He passes on the chalk to Dick. The next day, after Archie does not pay the Hobo for his work, the Hobo carves the sign for a dishonest man-a dagger-on the fence of the Whitman farm. Reverse shots cutting between the departing Hobo and Dick's father seal Dick's identification with a prohibition, a paternal interdiction that is based on a lack of honesty, an absence of truth. Dick, at his traumatic entry into the Symbolic, holds the means to navigate it-the chalk-and, turning to the path of the Hobo, he 
identifies with more than one man at the same time, initiating his capacity for duplicitous and ironic selfhood.

Recalling, as Edelman says, the letter as the site at which meaning comes undone, Dick solecistically and arbitrarily uses the detonation of bombs in Korea to assert a denotation 'against futurity, against its propagation', as the now dead commanding officer. He recodes himself as another man by switching dog tags, a Symbolic exchange of signifiers, but it merely 'designates an impasse in the passage to the future and, by doing so, would pass beyond, pass through, the saving fantasy future denotes'. Don's sinthomatic, ironic selfhood is continually tested against a future it cannot admit for it is based on death and the absence of truth, a false future that marches toward inevitable revelation and thus, unravelling. Stitching together Don Draper is precisely the function of melodramatic narrative in Mad Men, and it is imaged onto costume, the fetishistic fidelity of period detail, and the topological triangulation by California of the past and the present, seen in Don's movements away from his family and toward both the nomadic claques that refuse a typical family structure-after visiting Don and Joy in bed, it turns out Viscount Monteforte d'Alsace is Joy's father-and back to the original Mrs Draper, putting him into contact with the origin of his (self-)deception.

Another element in the parallel distribution of ironic selfhood is enacted according to an Edelmanian epistemology of the water closet when Pete excitedly tells Don that he saw Tony Curtis in the Los Angeles hotel bathroom-'A thing like that.' This is later counterpointed by Harry Crane's quip about which bathroom does the 'pervert' Kurt use: tellingly, this scene back in New York is shot with racking focus which keeps the closeted Sal's neutral demeanour sharp while Crane is fuzzy in the background, his voice providing the sound that denatures Sal's neutrality, forcing it to be a response to a queer jibe.

We can now recognise the significance of Sal's demeanour, the face of a man passing, when it was presented in the show's pilot, 'Smoke Gets In Your Eyes'. This episode is much more glib than those that follow and it lays down a central concern with a Freudian diagnosis of American society. ${ }^{43}$ The agency employs a severe, obviously European woman in its research department. She delivers a report to Sal and Don on how to sell cigarettes to an American public that knows tobacco causes cancer. She says in a heavy accent, 'Before the war, when I studied with Adler in 
Vienna, we postulated what Freud called the death wish is as powerful a drive as those for sexual reproduction and physical sustenance'. Sal responds, 'So we're supposed to believe that people are living one way, and secretly thinking the exact opposite? That's ridiculous.' At this stage, we might postulate Sal's homosexuality based on his European demeanour, or a certain flickering of eyelids. Only later, utilising the structure of hysteron proteron, can we re-read the scene as an emblematic statement of ironic selfhood.

Comparing Paul de Man's analysis of irony with the Lacanian death drive, Edelman writes:

The mindless violence of this textual machine, so arbitrary, so implacable, threatens, like a guillotine, to sever the genealogy that narrative syntax labors to affirm recasting its narrative 'chain of ... events' as a 'signifying chain' and inscribing in the realm of signification, along with the prospect of meaning, the meaningless machinery of the signifier, always in the way of what it would signify. Irony, whose effect de Man likens to the syntactical violence of anacoluthon, thus severs the continuity essential to the very logic of making sense. 44

Anacoluthon (beginning a sentence that implies one resolution but finishing it unexpectedly) is a favourite figure of advertisers: 'With a name like Smuckers it has to be good'. ${ }^{45}$ The dissonance smarts and draws our attention to the object that grounds the contradictory figure. Sal's 'That's ridiculous' requires, in its initial utterance, an impossible, preposterous memory of the future where his homosexuality has been revealed; irony makes an anacoluthonic utterance into what Benjamin reconfigured as a Penelopean forgetting, that which attempts to stave off the inevitability of revelation, just as Don must remember to forget. He must sever the continuity of Dick (enacting, in some sense, the wish his mother should have lived to see) in order to be Don.

\section{-CATASTROPHIC MEN: LETTERS AND REDESCRIPTIONS}

Following the lead of the series pilot, it is in this ironic mode that we must read Don's voice-over narration of the final three stanzas of 'Mayakovsky', the final poem of Meditations in an Emergency, that accompanies the sending of the collection to Anna before Don travels to California himself. He signs the missive, 'Made me think 
of you -D'; that is, it made Don think of himself as Dick, which he indicates by the letter, asking Anna to begin acrostically confirming his alternative identity by playing the Places game, to extend the meaning of the terminal letter-D.

Now I am quietly waiting for

the catastrophe of my personality

to seem beautiful again,

and interesting, and modern.

...

It may be the coldest day of

the year, what does he think of

that? I mean, what do I? And if I do,

perhaps I am myself again. ${ }^{46}$

Vladimir Mayakovsky is to O'Hara as the original Don Draper is to Dick Whitman, and as the ironic Don is to the ' $\mathrm{I}$ ' of the poem. This is a confusing, 'suddenly turning', contingent selfhood of the sinthomosexual and Rortean ironist, a veritable catastrophe of personality:

We redescribe ourselves, our situation, our past, in those terms and compare the results with alternative redescriptions which use the vocabularies of alternative figures. We ironists hope, by this continual redescription, to make the best selves for ourselves that we can. ${ }^{47}$

For this redescription to be beautiful again - the repetition of 'again' at the poem's end redoubles its serial quality - the catastrophe must (re-)emerge. 'Cata-' has the sense of being against, of being reflected back, and a 'strophe' is a turning. The direct, denotative beauty of the original Greek, $\kappa \alpha \tau \alpha \sigma \tau \rho \circ \phi \eta$, is hidden or submerged by translation and by the early modernity of 'personality', which first emerged as an aspect of the Trinity in the fifteenth century and became a name for a person's individual character in the eighteenth century. Dr Johnson defines 'catastrophe' as a 'final event; a conclusion generally unhappy'; ${ }^{48}$ 'Hara and Don want the final event to happen again as they redescribe their relations to other men, whom they become by their ironic work.

The finale of season five, which is set at Easter and includes that season's few direct references to California when Pete asks Beth to escape with him to Los Angeles, finishes with the theme from the James Bond film You Only Live Twice 
accompanying a montage of different characters' current places in life. The song begins as Don walks away from the set of a commercial shoot that has transformed his latest wife, Megan Calvert, into the casting director's idea of a European Beauty from Beauty and the Beast. Butler Shoes have chosen this 'theme' to tune into people's dreams so it can furnish them with its products. The song demarcates this world of fantasy from the real as the televisual space of the commercial set diminishes in the background as the camera tracks Don walking toward the viewer and into darkness: 'You only live twice or so it seems / One life for yourself and one for your dreams'. Don re-emerges by the arbitrary logic of on-action cutting (and stitched together by the continuation of the song) in a bar, where he sits and orders an Old-fashioned. The season ends with his wife in a cinematic (if déclassé) space that Don traverses, moving to, for the moment at least, where he began the series: smoking and drinking in a bar. This may be an 'unhappy conclusion' because Don, who has remained uncharacteristically monogamous throughout season five (even hallucinating strangling a past mistress who threatened his marriage during a fever dream), is propositioned by an attractive young woman. He pauses for a soap operatic length of time, turns his head, and the season ends before he gives an answer.

California is an important space for Mad Men's critical mode of representation because the plasticity and diversity of its people, its social and intimate relations, and its cinematicity allow the violent and complex work of irony to be grounded in both the present and the past. This, in turn, makes coherent the ironic selfhood of Don Draper without betraying its roots in art cinema and melodrama. What results is not necessarily a queer Don Draper but a redescribed Don that utilises the arbitrary and excessive network of sinthomosexuality to move between different versions of himself. The smooth operation of his contemporary ironic selfhood is begun by violent death, punctuated by suicide, and continually worried by the threat of revelation that occurs whenever the past forces itself to push through into the present, a present of which it-the past-is an indispensable component. Don is a serial and solecistic man, a Mad Man. And so is it any wonder that Don, when he returns to California in season four with his kids and secretary in tow, proposes to his secretary, Megan? Given the fluidity, seriality and parallel distribution of Don's queer narrative work to make himself Dick again-missives, nomads, missiles, 
ready-made wives - that he re-experiences in La-La Land, the passing of a human artifact, the engagement ring from the original Don Draper to the original (now deceased) Mrs Draper to the current Don Draper to Megan, Don's secretary and future Mrs Draper, is a continuation of the circulation of self we saw when Don mailed Meditations in an Emergency to Anna. If Don was attracted to the decadent Europeanness of Joy and her nomadic family and friends-that same Europeaness that allows Smitty to deflect Kurt's homosexuality, signals Sal's homosexuality, allows the Drapers to role-play in a Felliniesque Rome, and gets Megan cast as Beauty for the Butler Shoes commercial-then the French-Canadian whiz with kids (or, 'Maria von Trapp' as Don calls her) lets Don redescribe the last line of O’Hara's poem: 'perhaps I am myself again'.

Rodney Taveira is a lecturer in American Studies at the United States Studies Centre, University of Sydney. He has published on contemporary American fiction, literary responses to $9 / 11$, and the interrelation of cinema, photography, painting and literature.

\footnotetext{
-NOTES

${ }^{1}$ Quoted in Michael S. Kimmel, The History of Men, SUNY Press, New York, 2005, p. 8.

2 Larry E. Ribstein, 'How Movies Created the Financial Crisis', Michigan State Law Review, Winter 2009, p. 4, University of Illinois Law \& Economics Research Paper No. LE09-029,

<http://ssrn.com/abstract=1498702>, p. 4.

3 Slate and The Guardian both host weekly blogs that critically appraise each episode during a season's run. Users scour the internet for historical references to confirm the show's fidelity to period.

${ }^{4}$ Ribstein, p. 8.

5 Ibid.: 'Although Madoff's prosecution should surprise no one given the egregious nature of his crime, the septuagenarian's 150 year sentence should raise eyebrows when juxtaposed with lesser sentences of career criminals who deal drugs, kill and rape.' See the comments to Marc Abrahams, 'Improbable Research: It's Movies that Made the Crisis a Financial One', The Guardian, 31 May 2010,

<http://www.guardian.co.uk/education/2010/may/31/improbable-research-financial-crisis>. While
} 
the article merely describes Ribstein's paper, its appearance in the newspaper's 'Improbable Research' series frames Ribstein's argument as, at best, questionable.

${ }^{6}$ Ribstein, p. 3.

7 Ibid.

8 Ibid.

9 Daniel Mendelsohn, 'The Mad Men Account', The New York Review of Books, 24 February 2011, <http://www.nybooks.com/articles/archives/2011/feb/24/mad-men-account/>.

10 Ibid.

11 Ibid.

12 Carl Abbott, The Metropolitan Frontier: Cities in the Modern American West, University of Arizona Press, Tucson, 1993, p. 176.

13 This marks the only time the actors 'from' Don's childhood and Jon Hamm, who portrays Don Draper, have worked in the same physical space. This detail comes from the actress who plays Abigail Whitman: AMC, 'Q\&A Brynn Horrocks (Abigail Whitman)', Mad Men Blog, 23 June 2010, <http://blogs.amctv.com/mad-men/2010/06/brynn-horrocks-interview.php>.

14 Jane Feuer, 'HBO and the Concept of Quality TV' in Quality TV: Contemporary American Television and Beyond, ed. Janet McCabe and Kim Akass, I.B. Taurus, Sydney, 2007, p. 148.

15 Matt Zoller Seitz argues that AMC is now also 'a synonym for excellence' in television production, its shows 'all novelistic series with season-length interlocking stories'. 'The Extraordinary Rise of AMC', Salon.com, 23 Nov 2010, <http://entertainment.salon.com/2010/11/23/amc_versus_hbo/>.

16 Feuer, p. 151.

17 Ibid., p. 152.

${ }^{18}$ Sigmund Freud, The Psychopathology of Everyday Life, ed. James Strachey, trans. Alan Tyson, Hogarth, London, 1960, p. 43.

${ }^{19}$ Musing on her foundational family stories, Californian native Joan Didion writes, 'This moment of leaving, the death that must precede the rebirth, is a fixed element of the crossing story. Such stories are artlessly told. There survives in their repetition a problematic elision or inflation, a narrative flaw, a problem with point of view: the actual observer, or camera eye, is often hard to locate', Where I Was From, Vintage, New York, 2003, p. 30.

${ }^{20}$ Feuer, p. 149.

21 Nina C. Leibman, Living Room Lectures: The Fifties Family in Film and Television, University of Texas Press, Austin, 1995, p. 6.

22 Ibid., p. 38.

${ }^{23}$ In Leibman, p. 23.

${ }^{24}$ Liebman, p. 39: 'television programs in particular evidenced an extreme attention to detail; like their filmic counterparts, television homes were cluttered with an assortment of knickknacks and appliances 
whose metaphoric signification extends beyond domestic anxiety into the realm of consumptive entrapment.'

25 'The three leading states of California, Texas, and Washington received 14\% of prime contracts during World War II, 20\% during the Korean War, and more than 33\% by the end of the 1950 s.' Abbott, p. 57.

${ }^{26}$ So overdetermined is this partnership, and the way it signifies queerly, that the two actors are interviewed at the same time for AMC's extensive website for the show. They are asked if they auditioned together, and if they spend time together off-screen, <http://blogs.amctv.com/madmen/2009/10/kurt-and-smitty-interview.php>. Unlike the interviews with other actors, the url contains their character names, not their real names.

27 Richard Rorty, 'Philosophy of a Transitional Genre', Pragmatism, Critique, Judgment: Essays for Rickard J. Bernstein, ed. Seyla Benhabib and Nancy Fraser, MIT Press, Cambridge, 2004, p. 10.

28 Mike Davis, City of Quartz: Excavating the Future in Los Angeles, Vintage, New York, 1992, p. 50.

${ }^{29}$ Davis takes the Remarque quote from Wagner's Los Angeles ... Zweimillionenstadt in Sudkalifornien, published in 1935.

30 Ed Gali, who plays Kurt, comments of his character's clothes: 'Mine are even more out of this world. Those yellow sweaters, it's like a highlighter. When we come on the set, literally everyone stops and stares', 'Q\&A-Edin Gali (Kurt) and Patrick Cavanaugh (Smitty)', AMC Mad Men blog, <http://blogs.amctv.com/mad-men/2009/10/kurt-and-smitty-interview.php>.

31 The set for Rome reproduces that for California and reinforces the connection to art cinema, according to Chris Manley, the show's director of photography: 'I'm a big, big Fellini fan, and so is Matt [Weiner]. La Dolce Vita and $81 / 2$ were in my mind but there was no specific reference. The locations and sets were so different than what we were used to shooting, they called for a different look. I did a style of light that you don't often see in the show. The film we used felt right. The sets that Dan Bishop designed were similar to sets in "The Jet Set”.' AMC, Interview with Chris Manley, Mad Men blog, <http://blogs.amctv.com/mad-men/2009/10/chris-manley-interview.php>.

32 Michael S. Kimmel, Misframing Men: The Politics of Contemporary Masculinities, Rutgers University Press, New Jersey, 2010, p. 2.

33 Ibid., p. 2.

34 Abbott, p. 176.

35 Norman M. Klein, The History of Forgetting: Los Angeles and the Erasure of Memory, Verso, New York, 1997, p. 103.

36 Walter Benjamin, Illuminations, Schocken Books, New York, 1968, p. 202.

37 Lee Edelman, No Future: Theory Queer Theory and the Death Drive, Duke University Press, Durham, 2004 , p. 33.

38 Ibid., p. 42.

39Ibid., p. 101, n. 51. 
40 Ibid., p. 3.

41 Ibid., p. 35.

42 The Hobo initially thought that Dick's refusing to acknowledge that Abigail was his mother was Dick simply playing his part in the Freudian family romance: 'We also wish we were from someplace else'; 'The child's imagination', says Freud, 'becomes engaged in the task of getting free from the parents of whom he now has a low opinion and of replacing them by others, who, as a rule, are of higher social standing'. Sigmund Freud, 'Family Romances', The Standard Edition of the Complete Psychological Works of Sigmund Freud, vol. 9, ed. James Strachey, trans. Alan Tyson, Hogarth, London, 1959, pp. 237-8. ${ }^{43}$ Series creator Matthew Weiner has made repeated references to Freud during interviews. On a female character who want sleep with a man who doesn't have a condom: 'Because people sometimes "repeat to master": She would want to have unprotected sex again—and not get pregnant—to undo that problem. It's human behavior. People want to know how we come up with unexpected twists? We just do the stuff people actually do', John Swansburg, 'A Conversation with Matthew Weiner', Slate.com, 21 March 2012,

<http://www.slate.com/articles/arts/interrogation/2012/03/mad_men_creator_matthew_weiner_on_ season_5_html>. On the finale to season five: 'Freud defined happiness as the ability to work and to love', John Swansburg, 'A Conversation with Matthew Weiner', Slate.com, 11 June 2012,

$<$ http://www.slate.com/articles/arts/interrogation/2012/06/mad_men_finale_matt_weiner_interview _on_season_5_final_episode_the_phantom_html>.

${ }^{44}$ Edelman, p. 23-4.

45 Another example: The anachronism of period drama means Don's assessment of Los Angeles reads as an anacoluthon: 'Everything is new, and it's clean. The people are filled with hope.'

46 Frank O'Hara, Meditations in an Emergency, Grove Press, New York, 1967, p. 51-2.

47 Richard Rorty, Contingency, Irony, and Solidarity, Cambridge University Press, Cambridge, 1989, p. 80.

${ }^{48}$ Samuel Johnson, A Dictionary of the English Language, J. F. and C. Rivington, London, 1785, <http://www.archive.org/details/dictionaryofengl01johnuoft>. 